Sari Pediatri, Vol. 8, No. 4, Maret 2007: 316 - 321

\title{
Kasus Kekerasan pada Anak Sekolah (School Bullying)
}

\author{
Fiva A.Kadi , Eddy Fadlyana*
}

\begin{abstract}
Abstrak. School bullying atau kekerasan pada anak di sekolah adalah situasi/ keadaan yang seorang anak mendapat perlakuan tidak menyenangkan dari teman atau kakak kelasnya berupa bentuk tindakan kekuasaan secara berulang dan intensif yang menyebabkan nyeri atau ketidaknyamanan pada anak lain. Hal ini dapat terjadi di berbagai tingkat sekolah, mulai sekolah Taman Kanak-kanak sampai perguruan tinggi. Dilaporkan seorang anak perempuan berusia 7 tahun datang ke poli Tumbuh Kembang Pediatrik Sosial RS Hasan Sadikin dengan keluhan utama sering pusing pada pagi hari setiap akan pergi ke sekolah, yang mulai dirasakan dalam 3 bulan terkahir. Tidak disertai dengan keluhan demam, mual, muntah, kejang ataupun penurunan kesadaran dan tidak didahului dengan trauma kepala. Pasien mengalami tekanan dari teman-temannya di kelasnya berupa ejekan atau perintah yang membuat penderita tidak nyaman, malas pergi ke sekolah, sering pusing jika di sekolah atau mau pergi ke sekolah, prestasi belajar mulai menurun. Pada pemeriksaan fisik didapatkan pasien sadar dan kontak adekuat, tampak malu dan bergantung pada ibunya serta kurang percaya diri. Tidak ditemukan kelainan neurologis. Pemeriksaan EEG dan CT scan dalam batas normal. Pemeriksaan praskrining dengan KMME (kuesioner masalah mental emosional) didapatkan adanya masalah mental emosional. Penderita dirujuk ke bagian psikiatri dan didapatkan bahwa penderita mengalami depresi. Depresi pada anak dapat disebabkan adanya kekerasan pada anak sekolah (school bullying). Penatalaksanaan harus dilakukan secara komprehensif yang melibatkan keluarga dan lingkungan.
\end{abstract}

Kata kunci: school bullying, depresi pada anak.

S

hool bullying atau kekerasan pada anak di sekolah adalah situasi/ keadaan yang seorang anak mendapat perlakuan yang tidak menyenangkan dari teman atau kakak kelasnya berupa bentuk tindakan kekuasaan secara berulang dan intensif yang menyebabkan nyeri atau ketidaknyamanan pada anak lain. ${ }^{1}$ Kasus ini sudah

\footnotetext{
Alamat korespondensi:

Dr. Eddy Fadlyana, Sp.A

Bagian/SMF Ilmu Kesehatan Anak FKUP/RSUP dr. Hasan Sadikin Jl. Pasteur No. 38

Telepon/Fax. 2034426-203595 Bandung 40161
}

menyebar di berbagai tingkat sekolah, mulai sekolah taman kanak-kanak sampai perguruan tinggi. Di Amerika Serikat pada tahun 2004 ditemukan 86\% anak sekolah dasar mengalami school bulying oleh teman atau kakak kelasnya dan $42 \%$ terjadi di sekolah lanjutan lainnya. ${ }^{2}$ Data di Indonesia belum ada.

School bullying dapat ditemukan dalam bentuk bullying dari seorang kakak kelas terhadap adik kelasnya, teman sekelas yang secara fisik atau sosial berbeda dari teman lainnya. ${ }^{3}$ Ada dua (2) macam tindakan school bullying, yaitu direk (langsung) dan indirek (tidak langsung). Tindakan secara langsung 
dapat berupa serangan fisik langsung pada korban, sedangkan tindakan tidak langsung dapat berupa isolasi sosial pada seorang anak atau seorang anak dikeluarkan dari suatu kelompok. ${ }^{4,5}$ Dijumpai tiga kunci pada tindakan bullying, yaitu adanya ketidakseimbangan kekuatan, bertujuan negatif dan berulang. ${ }^{4}$ School bullying merupakan salah satu penyebab terjadinya depresi pada anak dan remaja. Depresi yang terjadi pada anak dan remaja dapat mempunyai prognosis buruk jika didiamkan. Dengan mencegah terjadinya school bullying, berarti kita juga mencegah timbulnya depresi pada anak. ${ }^{1-5}$

\section{Kasus}

Seorang anak perempuan, K, 7 tahun, BB: $30 \mathrm{~kg}$, TB: $130 \mathrm{~cm}$, datang ke Poli Tumbuh Kembang RS Hasan Sadikin Bandung pada tanggal 11 Juni 2006 dengan keluhan utama sering pusing pada pagi hari. Sejak 3 bulan sebelumnya pasien sering mengeluh pusing. Pusing dirasakan terutama jika pagi hari ketika akan pergi ke sekolah atau pada saat di sekolah dan akan menghilang jika pasien sampai di rumah dan menonton televisi. Keluhan tidak disertai demam, mual, muntah, kejang ataupun penurunan kesadaran, dan tidak didahului dengan trauma kepala. Buang air kecil dan buang air besar tidak ada keluhan. Karena keluhannya tersebut pasien dibawa ke dokter umum, dilakukan pemeriksaan EEG dan CT scan kepala dengan hasil normal, demikian juga hasil pemeriksaan laboratorium darah normal, kemudian disarankan untuk berobat ke RSHS ke Poli Tumbuh Kembang.

Pasien adalah anak pertama dari ibu P2A0. Lahir normal dengan berat lahir $3 \mathrm{~kg}$, panjang lahir $48 \mathrm{~cm}$. Mulai tengkurap usia 4 bulan, merangkak 5,5 bulan, duduk 7 bulan, berdiri 9,5 bulan, berjalan 12 bulan, dan bicara jelas 14 bulan. Sejak usia 3 tahun pasien sudah sekolah di Taman Kanak-kanak, usia 5 tahun masuk Sekolah Dasar dan saat ini sekolah kelas 2 di salah satu SD di Bandung dengan nilai rapor baik, mendapat rangking 3 besar di kelasnya diantara 45 murid.

Riwayat kuning setelah lahir tidak ada. Riwayat kejang dengan atau tanpa panas tidak ada. Riwayat kontak dengan penderita TB dewasa tidak ada. Imunisasi BCG diberikan pada usia 1 bulan, skar (+). Pada kedatangan pertama pasien lebih banyak diam, duduk selalu memegang tangan ibunya dan tidak mau banyak bicara, dan ibunya lebih banyak becerita.

Pasien datang kedua kalinyadengan ibunya dan mulai bisa diajak bercerita. Pasien mengeluh pusing, mulai terasa pada pagi hari setelah mandi dan akan pergi ke sekolah, kadang timbul di sekolah. Di sekolah anak mempunyai teman grup berjumlah lima orang yang semuanya wanita. Pasien merupakan anggota termuda dari grupnya, oleh teman lainnya ia selalu diperintah untuk melakukan keinginan mereka. Bila tidak mau pasien dimusuhi dan diejek. Bila jajan, pasien harus menunggu perintah dari ketua grupnya jajanan apa yang harus dibeli. Karena tidak tahan, 3 bulan yang lalu pasien keluar dari grupnya, tetapi kemudian pasien malah menjadi ejekan grupnya. Bila bertemu, pasien diejek, semua kegiatan atau peralatan yang dibawanya selalu dikomentari.

Pada pemeriksaan fisis didapatkan keadaan umum kompos mentis, kontak adekuat, keluhan pusing pada saat pemeriksaan tidak ada. Tekanan darah 100/60 $\mathrm{mmHg}$, tanda vital lainnya dalam batas normal. Tidak ditemukan kelainan neurologis. Pemeriksaan darah rutin normal. Hasil EEG dan CT scan yang dibawa dari laboratorium swasta normal. Pada hari kedua dilakukan uji preskrining KMME (kuesioner masalah mental emosional); dari 12 pertanyaan didapatkan 3 jawaban ya, disimpulkan pasien mengalami masalah mental emosional. Pasien selanjutnya dikonsultasikan ke Bagian Psikiatri untuk tindakan selanjutnya; hasil konsultasi menerangkan bahwa anak mengalami depresi. Pasien direncanakan untuk diberikan psikoterapi.

Tindakan saat ini, sudah dilakukan komunikasi antara orang tua pasien - guru (wali kelas) - tim tumbuh kembang untuk penyelesaian masalah tersebut. Direncanakan akan dilakukan pertemuan kembali antara pihak sekolah, orang tua, dan IKARSHS untuk membahas cara pencegahan agar masalah tersebut tidak terulang kembali.

\section{Diskusi}

Diagnosis school bullying pada anak ini ditegakkan berdasarkan atas adanya keluhan somatik berupa pusing kepala yang timbul dalam tiga bulan terakhir. Keluhan somatik berupa pusing kepala mulai timbul setelah anak mengalami suatu tekanan dari temantemannya, demikian juga dengan prestasi sekolah menurun serta perilaku yang berubah. Tidak disertai dengan keluhan yang mengarah pada penyakit 
tertentu, tidak didahului dengan trauma kepala, pemeriksaan fisis dan pemeriksaan penunjang dalam batas normal.

Bullying merupakan suatu bentuk dari kekerasan, pada keadaan tersebut seseorang atau suatu grup akan menunjukkan bentuk kekuasaan pada orang lain atau kelompok lain yang dinilai kekuatannya di bawah orang/grup itu. ${ }^{5}$ Bullying merupakan tindakan yang dilakukan dengan niat untuk menyakiti orang lain baik secara fisik maupun emosional. Tindakan itu tidak selalu dalam bentuk aksi seperti memukul, menendang, mengejek atau menghina, bisa dalam bentuk tidak langsung seperti penyebaran gosip di lingkungan orang tersebut berada, mengeluarkan dari suatu kelompok ataupun pengucilan terhadap seseorang/anak. ${ }^{1,6}$

Sangat sulit untuk mengetahui seorang anak mendapatkan school bulying atau tidak, karena biasanya seorang anak menyembunyikan keadaannya di sekolah. ${ }^{2,3}$ Tanda yang utama pada anak yang mengalami school bulying biasanya bersikap depresi dan kurang percaya diri. Kesenangan pergi ke sekolah menjadi hilang dengan berbagai alasan, biasanya disertai keluhan berupa mual atau pusing/nyeri kepala setiap akan pergi ke sekolah sebagai alasan untuk tidak sekolah. Pada pemeriksaan fisikpun tidak ditemukan kelainan. ${ }^{2}$

Beberapa jenis school bullying, yaitu, ${ }^{2}$

1. Cyber-bullying: merupakan fenomena baru, komunikasi modern mulai umum dipakai. Bentuknya dapat berupa e-mail, instans messaging atau gambar-gambar.

2. Emotional bullying: dapat berupa mengisolasikan seorang anak dari aktivitas atau teman sepermainannya, membicarakan seseorang atau mempermalukannya di tempat umum atau menyebarkan gosip-gosip yang belum tentu benar. Keadaan ini lebih sering terjadi pada anak perempuan.

3. Physical bullyingI : dapat dilakukan bersamaan dengan verbal bullying dan biasanya disertai dengan suatu tindakan kekerasan seperti dipukul, ditendang perampasan/pengrusakan barang atau kekerasan fisik lainnya. Biasanya hal ini dilakukan pada anak laki-laki.

4. Racist bullying : berupa cela-celaan pada salah satu adat atau kultur tertentu.

5. Sexual bullying : termasuk kontak seksual atau pembicaraan tentang seksual yang tidak diinginkan oleh seorang anak.
6. Verbal bullying: berupa ejekan-ejekan dengan nama yang buruk, mentertawakan tingkah laku seseorang di tempat umum ataupun berupa katakata kasar atau keras untuk mempermalukan seseorang.

Proporsi jenis school bullying yang lebih sering terjadi, tertera pada gambar $1 .{ }^{1}$

Beberapa macam penyebab seseorang menjadi bully kids (anak yang menyakiti). Kebanyakan bully kids mencari target anak yang berbeda dari lingkungannya, berbeda dalam penampilan fisik misalnya gemuk, memakai kacamata, berjerawat atau secara sosial berbeda

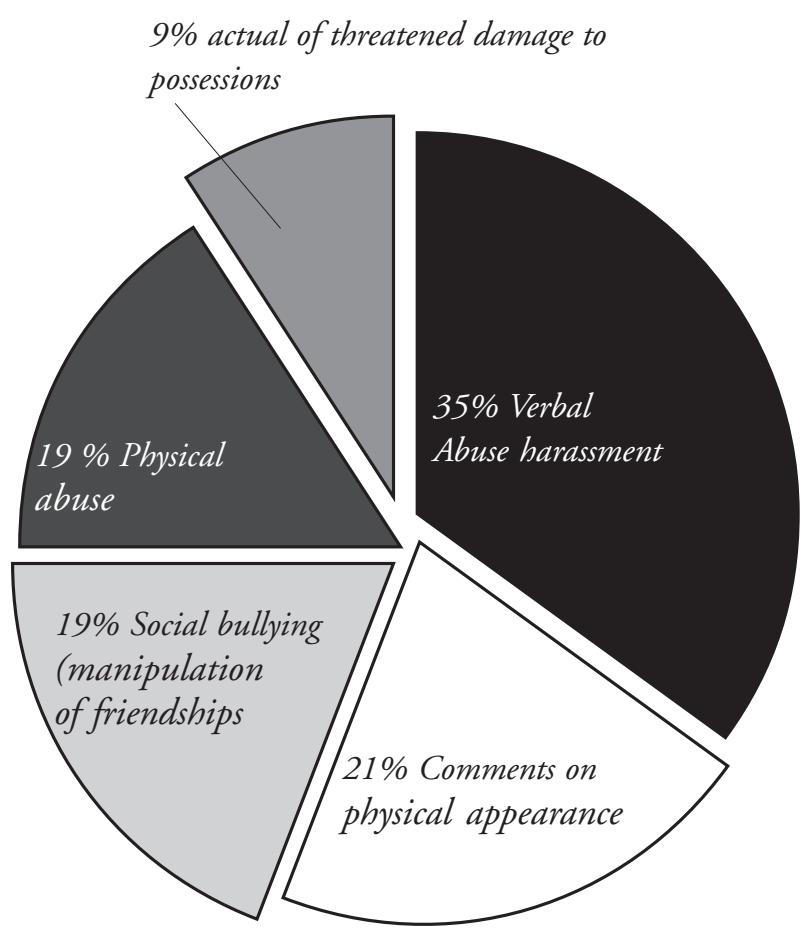

Gambar 1. Bentuk School Bullying

Gunter, Margaret.(2003). Bullying victimsface increased mental health risk.

dengan lingkungan lainnya. Anak tersebut menjadi bahan tertawaan di tempat umum dan menjadi gunjingan di lingkungannya. Korban terpilih apabila menurut mereka anak tersebut tidak mungkin dapat membalas dendam. Keinginan pelaku, target mengalami kecemasan dan ketidaknyamanan. ${ }^{1-6}$ Bully kids biasanya mempunyai latar belakang yang tidak menyenangkan, dapat berupa kejadian di rumah seperti perceraian sehingga timbul rasa 
kurang percaya diri pada seorang anak, anak tersebut ingin menunjukkan jati dirinya karena mereka jarang mendapatkan perhargaan atas diri atau prestasinya, atau berasal dari keluarga yang sering bertengkar atau sering mendapat perlakuan keras/ kata kasar, sehingga mereka ingin membalas. ${ }^{2,6}$ Kebanyakan bully kids selalu merasa bahwa perilaku mereka adalah normal, karena mereka sering melihat kondisi yang dia lakukan dalam lingkungannya. Mereka akan meniru kondisi yang sudah terbiasa mereka dapatkan. ${ }^{2}$ Bully kids akan merasakan suatu perasaan lebih diakui, lebih populer dan dapat mengontrol semua keadaan, membuat dia merasa lebih nyaman. ${ }^{2}$ Efek jangka panjang dari bully kids adalah anak tersebut dapat menjadi anak yang anti-sosial, agresif, atau senang merusak. Dari suatu penelitian didapatkan bahwa 60\% anak laki-laki yang menjadi bully kids akan menjadi seorang_kriminal atau seorang yang gemar menyakiti, $23 \%$ terjadi pada wanita. ${ }^{2,5,6}$

Ada beberapa tanda-tanda yang dapat diamati pada anak-anak yang mengalami school bullying (bullied kids) target), yaitu 2,3

- Adanya keluhan setiap akan pergi dan pulang sekolah, seperti pusing, mual

- Hilangnya beberapa barang atau uang

- Gangguan tidur

- Ngompol

- Konsentrasi menurun

- Perubahan prilaku

- Kesulitan dalam membuat pekerjaan sekolah Korban school bullying mempunyai efek jangka panjang. Anak akan mempunyai kesulitan untuk bersosialisasi dengan anak yang lebih besar atau yang menurut dia lebih senior. Untuk kasus yang lebih berat anak dapat menjadi depresi dan mudah cemas. ${ }^{1-6}$

Mengidentifikasi anak depresi agak sukar, karena harus memisahkan gejala fisik akibat tekanan psikologis. Bentuk umum gejala depresi pada anak dan remaja secara umum hampir sama dengan dewasa, tetapi bermanifestasi dengan gejala tambahan sesuai usia anak. ${ }^{7}$ Anak lebih sukar mengutarakan perasaannya dan sering menyatakan perasaannya dengan tingkah laku yang ditujukan pada orang lain. ${ }^{7,8}$ Wathin CE menyatakan bahwa gejala eksternal dari depresi pada anak atau remaja yaitu: ${ }^{9}$

1. Anak pra sekolah dan usia sekolah pada tingkat SD awal (young elementary age)

Menunjukkan gejala fisik yang samar sampai serius. Anak kurang spontan menyatakan emosinya, menjadi mudah gelisah atau mudah menangis.
2. Anak usia sekolah akhir (SD akhir) sampai remaja. Pada usia ini lebih menunjukkan gejala depresi seperti penurunan prestasi akademik, penyimpangan tingkah laku atau bermasalah dengan hubungan teman.

Penelitian akhir-akhir ini menyatakan bahwa depresi pada usia sekolah dan remaja lebih banyak disebabkan karena kehilangan harga diri (loss of self worth or self esteem) daripada kehilangan orang yang dicintai (loss of loved care take). Depresi usia sekolah dan remaja disebabkan karena 3 hal (triad cognitive), yaitu perasaan tak berharga (worthlessness), perasaan tak ada yang menolong (helplessness), dan perasaan tak ada harapan (hopelessness). ${ }^{9}$

Menurut Patterson dan Capaldi (1990), depresi pada anak sekolah terjadi karena adanya tingkah laku antisosial yang disebabkan penolakan dari orang tua atau teman-temannya, sehingga mengakibat penurunan harga diri dan kemampuan akademik, dan menyebabkan depresi pada anak. Jadi, adanya mediator berupa harga diri yang rendah, penolakan dari teman disertai dengan kemampuan akademik yang menurun akan menimbulkan depresi pada anak. ${ }^{9}$

Pada tata laksana untuk mengatasi masalah school bullying harus melibatkan orang tua murid dan sekolah, kebijaksanaan yang dibuat harus dilakukan baik di rumah maupun di sekolah. Terapi yang diberikan ditujukan pada kedua pihak, baik bully kids maupun target. ${ }^{1-6}$

\section{Peran orang tua di rumah}

- Jadi pendengar yang baik. Berbicaralah dengan lembut pada anak, jadilah pendengar yang baik. Jangan memberikan respon negatif dalam bentuk apapun (seperti marah, rasa tidak senang, komentar kasar).

- Jangan menyalahkan. Berikan dorongan dan dukungan

- Berikan pengertian pada anak dengan bahasa yang mudah dimengerti bahwa bila masalah ini dibiarkan akan dapat berulang pada orang lain dan akan menjadi masalah yang berkepanjangan.

- Berikan pengertian bahwa suatu bentuk pertemanan adalah saling mendukung satu sama lainnya, bukan saling menjatuhkan atau saling menyakiti.

- Buatlah suatu bentuk tata krama/kebiasaan yang baik di rumah sebagai contoh.

- Berikan dorongan pada anak untuk menceritakan bila dia mengalami school bullying. 
- Berikan tips untuk menghadapi school bullying,

o Tahan kemarahan, kemarahan tidak akan menyelesaikan masalah.

o Jangan membalas tindakan school bullying Tanamkan pengertian bahwa membalas berarti membuat kita sama tidak baiknya seperti pelaku. Lebih baik diam untuk mencari aman dan pergi menjauh, abaikan semua tindakan pelaku.

o Jangan takut, katakan pada anak kita jangan menunjukkan rasa takut pada pelaku, tatap matanya seolah-olah berkata "hentikan perbuatanmu", karena semakin kita tampak takut, semakin senang pelaku.

o Pakai humor, meminta anak untuk mencoba melucu jika terjadi school bullying. Tapi jangan yang berupa ejekan terhadap pelaku.

o Buat suatu pertemanan yang kuat untuk menghadapi pelaku, sehingga pelaku akan berpikir ulang untuk berbuat jika target mempunyai suatu grup yang membela.

\section{Di sekolah}

- Terapkan peraturan sekolah, adakan hukuman bagi bully kids.

- Buat komunikasi yang baik antara muridorangtua-guru.

- Adakan pelaporan jika ditemukan adanya tindakan school bullying.

- Sekolah membuat biro konsultasi untuk semua pihak school bullying, baik bully kids maupun bullied kids.

Dengan kita melakukan pencegahan dan terapi school bullying pada anak, maka kita dapat mencegah salah satu penyebab depresi pada anak. Hal penting dalam tata laksana depresi adalah deteksi adanya depresi secara dini. Wawancara harus dilakukan dengan hati-hati. Beberapa pegangan untuk mengetahui adanya depresi, ${ }^{10}$

1. Mencoba mengerti apa yang dipikirkan anak saat bercerita,

2. Perhatikan apakah anak tampak murung atau bertingkah laku depresi,

3. Apakah ada peristiwa yang berhubungan dengan perpisahan atau terjadi suatu perubahan dalam suatu hubungan, misalnya perpisahan, pertikaian,

4. Perkirakan adanya depresi terselubung jika anak dikonsulkan dengan prestasi sekolah yang mundur, atau terdapat keluhan somatik tanpa kelainan fisik.
Bila derajat depresi tidak terlalu berat dan belum berlangsung lama, serta keadaan keluarga relatif stabil, maka bimbingan dan konseling pada anak dan keluarga dapat membantu untuk menyelesaikan persoalan. Bila derajatnya sedang atau tinggi maka tata laksana selain melalui psikoterapi harus juga dilakukan dengan psikofarmakoterapi dan intervensi keluarga.

\section{Psikoterapi}

a. Terapi perilaku kognitif

- Berorientasi pada masalah, yaitu berusaha untuk mengatasi distorsi kognitif, anggapan salah dan harga diri buruk.

- Bertujuan mengurangi sikap menghukum dan menyalahkan diri sendiri dan meningkatkan kemampuan sosial.

b. Psikoterapi interpersonal

- Fase pertama bertujuan untuk identifikasi interpersonal yang menimbulkan kognisi depresi, diharapkan dapat terbentuk hubungan terapeutik untuk menetapkan tujuan khusus terapi.

- Fase kedua dikembangkan strategi untuk mengubah komunikasi interpersonal.

- Fase terakhir diterapkan cara-cara untuk mengubah komunikasi interpersonal.

c. Terapi keluarga

- Bertujuan untuk membantu keluarga mencapai keseimbangan kembali setelah terjadi suatu episode gangguan pada salah seorang keluarganya.

- Ciri terapi keluarga adalah .elibatkan seluruh anggota keluarga, dan fokus terapi adalah interaksi dalam keluarga. Tujuan terapi adalah menurunkan derajat depresi pada anak dan memperbaiki interaksi keluarga.

\section{Kesimpulan}

Depresi pada anak sulit dideteksi karena anak jarang menceritakan kejadian di sekolah, atau orang tua tidak punya waktu untuk mendengarkan keluhan anak selama di sekolah. Keluhan yang timbul biasanya berupa keluhan somatik, dapat berupa pusing, mual atau keluhan somatik lainnya, tetapi pada pemeriksaan fisis maupun laboratoris tidak diketemukan kelainan. School bullying merupakan salah satu penyebab terjadinya depresi pada anak. School 
bullying dapat menimbulkan rasa tidak dihargai, tidak dicintai dan harga diri yang direndahkan, sehingga timbul depresi. Depresi pada anak harus segera diidentifikasi secara dini karena bila tidak diterapi akan menjadi kronik dan prognosis pada anak menjadi buruk. Dalam penatalaksanaan harus dilakukan secara komperhensif dari kondisi anak, keluarga dan lingkungan sekitarnya agar tercapai hasil yang optimal.

\section{Daftar Pustaka}

1. Hot topics: Bullying behavior among school children. Arizona Prevention Resource center. Didapat dari http:/ www.azprevention.org/in_the_news/hot_topics/ hot_topics_bullying_intro.htm.

2. Kim. School bullying and suicidal risk in Korean middle school student; Pediatrics; 115; 2005.357-63.

3. Dowshen S, Pendley JS: Bullying and your child. No- vember 2004. Didapat dari : http://www.kidhealth.org/ parent/kh.misc/bullying in school/nemours.html

4. Gardens G: Bullying in school. Advisor Centre for Education. Didapat dari : www.childline.org.uk.

5. LeBlanc JC: Bullying, Its not just a school problem. Department of Pediatrics Psychiatry. Halifax, 2001; 6;7.123-6.

6. Quiroz HC : Bullying fact Sheet series. National school safety center. Didapat dari : www.bullying.org/help.html

7. Gardens G: Bullying. Advisor Centre for Education. Didapat dari : www.childline.org.uk.

8. Bismaher. Practice parameters for the assessment and treatment of children and adolescents with depressive disorders. J Amer.Acad.Child.Adolesc.Psychiatry, 1996. 37:63-83.

9. Gordon MS : Diagnosing and treatment depression in childhood and adolescents. Med.Progress.2000.33-7.

10. Wathin CE. Depression in children and adolescents. National Institute of Mental Health. Didapat dari : http/ lwww.nimh.nih.gov/studies/index.cfm.2000. 